\title{
Smart Road Technology for Traffic Management and ITS Infrastructure Assessment: A Case Study of Muscat Express Highway
}

\author{
Zamzam Said Abdullah Ali Al Mahairzi ${ }^{1}$, N. Srinivasa Reddy ${ }^{2}$

\begin{abstract}
${ }^{1}$ Under Graduate Student, Built and Natural Environment Department, Caledonian College of Engineering, Glasgow Caledonian University Muscat Sultanate of Oman,

${ }^{2}$ Senior Faculty Built and Natural Environment Department, Caledonian College of Engineering, Glasgow Caledonian University Muscat Sultanate of Oman.
\end{abstract}

\begin{abstract}
This technical work describe infrastructure requirement and the working principles and procedures involved in operation of a Smart Road. A Smart Road is similar to a conventional highway but the difference is, it is equipped with the electronic gadgets required to capture static and dynamic physical entities occupied on the road at a given time and location. Nowadays traffic safety and highway congestion has become a serious concern to the Authorities and required to be managed them within the available resources. Also it is not possible to increase the capacity of highway infrastructure to compete with increase in traffic. In cities on highway system, large amount of traffic data being generated and an integrated approach is required for the efficient management transportation system. Smart Road is an innovative approach wherein Information Communication Technologies (ICT) is merged with traditional infrastructure and integrated with digital technologies. Critical examination of literature review reveals that many technologies are available for data capturing and management. Notable among them are by using ultrasonic sensors, light sensors, motion sensors, camera and IOT devices. The data collected by the devices would be managed through cloud computing and big data analytic methods. To assess the current traffic situation spot speeds and traffic volumes are captured for peak and non-peak on the Express Highway and from the data captured $85^{\text {th }}$ percentile speed and LoS are estimated. Smart road technology is discussed for transportation system management. And IT infrastructure requirement for capturing traffic related data demonstrated for the selected road in Muscat.
\end{abstract}

Keywords - Smart Roads Traffic Congestion, IOT devices, Traffic Management through ITS RFID Camera for incident capture.

\section{INTRODUCTION}

Increasing traffic is of serious concern to the authorities in every city around the world. Muscat the capital city in Oman is suffering with varied traffic problems. The concern issues are speeding up of cars, increasing personalized vehicles and the big personal cars with low occupancy rate. The problems arising out of increased traffic are: increased congestion levels, over speeding of personal cars, travel delay times, loss to human life and property, increased pollution levels and retarded economic development. There is need to manage all the traffic related concerns in a smart way. To address all the listed problems and to find solutions a Smart Road using intelligent transportation system (ITS) is latest development and being adopted for arterial and sub arterial roads in cities across the world. Smart road is a road, wherein a normal road is equipped with variety of sensors and electronic gadgets which help in detecting the relevant problems and find feasible solutions to improve the operational efficiency of the system.

Smart Roads, Smart Cities, Smart Water Supply, Smart Systems etc is a very recent developments in urban planning, city planning transportation system management where the system components are efficiently managed with the support of electronic gadgets and sensors. Using Internet of Things (IOT) a virtual system will be created and which is similar to the real world situation. In case of a Smart Road a virtual road will be designed which is similar to the real road and all the real world data procured from the field monitored on the virtual systems and referred as the "Smart Road". Considerable research has been reported in literature review pertaining to Smart Roads. In this technical paper working principles of smart road is examined and infrastructure requirements for the conversion of a normal highway to a smart is established. Aim of the study is to assess the infrastructure required for the conversion an Urban Arterial Road with state Art Technology as a Smart Road. For this, a road segment of 
an existing urban arterial road is taken and demonstrated through a case study.

The specific objectives of the study would include:

- To study the working mechanism-principle involved in the operations of smart road.

- To estimate the infrastructure required for the conversion of a normal road to smart road.

- To assess the current traffic situation on an arterial road and suggest smart road technology.

- To evaluate the benefits of smart road quantitatively and qualitatively.

\section{Justification:}

Over the last the one decade traffic on Muscat roads is consistently increasing with an annual growth rate of $8.8 \%$. Increased traffic is resulting in frequent traffic delay and congestion. Even though the accident rate is declaiming in last decade the occurrence of number of accidents is of serious concern to the Royal Oman Police (ROP) and the Transport Ministry. A Smart Road is solution to address current traffic and transportation problems and to find cost effective solutions. Implementation of a smart road would reduce traffic jam on the roads, reduce the accidents, control on over speeding of vehicles and traffic engineering management. The other accrued benefits could be reducing pollution and reducing wastage in time and fuel. This is likely to improve economy and National development.

\section{Scope of Work:}

Over the last the one decade traffic on Muscat roads is consistently

Interaction with the Ministry of Transport and Communication and ROP officials for the selection of road segments for the implementation of smart road technologies. Collection of traffic speeds to assess the 85 th percentile speeds, for the quantification of benefits accrued due to implementation of smart road system. Assessment of infrastructure for the conversion of selected road to a smart road. Also Demonstration of implementation of smart technology to a highway system.

\section{Literature Review:}

The concept of the smart road is recent development. It basically use the technologies of intelligent transportation systems, information communication technologies with the application of big data analytics. Smart technologies are used for the management of cities in a smart way, to fuse the ideas about how information communications and technology to improve the functioning of cites for enhancing their efficiency and competitiveness and quality of life [1]. The working definition given by IBM research foundation for the smart city is "by connecting the physical infrastructure, the IT infrastructure, the social infrastructure, and the business infrastructure to leverage the collective intelligence of the city" [1]. In a smarter city the physical and social infrastructure entities are connected to a virtual city infrastructure in an integrated framework that allow the line managers to collect the data from different verticals, collate, analyze, optimize and take right decision within the available resources. The ICT infrastructure includes right from the information capturing, processing and end delivery to the user. The identified infrastructure would be deployed censors, cameras, distributed and centralized processing units, high power transmission band width units, software models and mobile units.

The concept of smart city emerged from a 2008 study the Instrumented Planet [2]. Spatial and temporal data of earth's geographical and geological entities are consistently captured through various instruments and sensors. Ubiquitous networks are available to collect real world data and the data is analyzed and integrated to manage urban information systems and often referred as smarter planet systems [2]. In smart city business and administrative operations of various entities are carried using ICT available from innumerable network available on the earth sphere and IBM has defined its view of a smarter planet system through three major IT characteristics, instrumented, interconnected and intelligent.

Instrumented: Real world data of various entities is captured through various gadgets like sensor, meters, cameras, appliances devices and data acquisition systems. The physical data is inter connected through networks to the virtual world of smart city systems. The data obtained from the real world entities is structurally organized and integrated and distributed to various organizations. For the integration of the collected from different entities to the virtual city, different search engines will be used. The structured information shall be retrieved at the user end through various search engines, queries and other IT tools for making intelligent decisions. The Instrumented Planet study showed that data on urban systems is captured consistently through Internet of things [3]. For the management of fleet, vehicular data and road safety innumerable number of telematics units, smart telephones and RFID tags were used in urban areas for the effective management of logistics and supply chain management [4, 5].

Cloud computing and storage solutions provide users and enterprises with various capabilities to store and process their data in either privately owned, or third-party data centers that may be located far from the user-ranging in distance from across a city to across the world[6]. The goal of cloud computing is to allow users to take benefit from 
all of these technologies, without the need for deep knowledge about or expertise with each one of them. The cloud aims to cut costs, and helps the users focus on their core business instead of being impeded by IT obstacles [7].in present day context in urban areas various organizations are depended on IT based management systems for their services and exchange information based on IT principle of interconnection among the edge clouds using service oriented architecture (SOA)[8].

The interconnection of multiple city services is an application of contemporary enterprise application integration to local government systems. It is a striking feature of the way that most cities are managed that, although city agencies have adopted some form of ITbased management system for their services, very few of them have the ability to exchange information. This appears to reflect the historical independence of such agencies and is reminiscent of the isolated operational towers of enterprises before the 1990s, when enterprise resource planning was broadly adopted to provide integrated management. Today, the basic IT principle for interconnection is the service-oriented architecture (SOA). Sonoma County is able to mange its water resources from Russian river for the effective management using the smart technologies[9]. In Stockholm the transport authorities are able to minimize the traffic problems and increase public transport ridership by capturing the data with increased number of sensors which are connected to the clouds[10]. The Singapore Land Transportation Authority (LTA) could predict the traffic congestions on roads and able to find solutions from the data collected by the ERP system[11]. IBM opened a Web site in March 2010 that is intended to provide tools to enable city managers and planners to visualize, analyze, and compare such data sets [12]. NiravThakoret.al (2013), used vibration and MEMS sensors embedded with GPS for the vehicle detection to provide immediate hospital for accident vehicle victims [13].

\section{METHODOLOGY}

Following steps are followed for the fulfilment of the objectives of the study.

- Collection of information, literature and case studies on smart road.

- Selection of a primary road stretch, after having discussions with the ROP and ministry of Transport officials.

- Conducting midblock spot speed studies for the quantification of 85th percentile speeds.

- Finally Assessment of requirement of IT infrastructure for the given selected segment of road to convert into a smart road.

\section{WORKING PRINCIPLE OF SMART ROAD}

The conventional traffic monitoring using image process technology is having many limitations and is affected by weather conditions. At times due to inclement weather vehicle image not captured. Whereas an e-plate based on radio frequency identification (RFID) provides a better opportunity for intelligent traffic monitoring for identifying and tracking the vehicle. RFID can be used as a transponder in license plate equipped with a RFID tag and sensors. For each car plying on the road it is mandatory for the vehicle to have an RFID tag for vehicle identification. The vehicle RFID tag stores information about the vehicle and the owner. Parameters such as vehicle plate number, vehicle type, speed of the vehicle, license number, the travelling location of the car are monitored and stored. This knowledge of information from every vehicle helps in estimating the number of vehicles on the road, average speed of the vehicles and the density of the vehicles on the road. The data from each vehicle is gathered or collected by means of a fixed or mobile RFID reader at each monitoring. Finally the information is sent to the central server for collecting, processing and storing. In a Smart Road number of transponders, radar guns and cameras are installed along the highway. All the vehicles are equipped with the RFID tags and when the vehicle is moving on the road, the vehicle's RFID tag is scanned by the sensor and the data is transmitted to the data systems. For data simulation and monitoring, a virtual road is designed, which is analogous to the real road and it contain all the information of physical road. The information captured on the road, interfaced with Geographical information Systems (GIS) is stored in the smart road system using the big data analytics and cloud technology. The basic IT principle followed for interconnection of objects in Smart Road System is by Service Oriented Architecture (SOA). In SOA approach all the objects captured on the road such as the vehicle data, speed data, level of service, capacity of the road, are processed and mapped and decisions will be communicated to the mobile data as well as variable massaging systems for traffic management. For the pilot study the data will be available to the users in web site. For the total road system the data will be managed and visible to the Ministry of Transport through Supervisory control and data acquisition (SCADA) is a system of software and hardware elements that allows industrial organizations to: Control industrial processes locally or at remote locations. Monitor, gather, and process real-time data. Smart road technology concepts are developed and demonstrated in the following lines.IT and IOT principles used in Smart Road systems are presented graphically in the following figure-1 and Figure-2. From the diagram it can be seen that the data procured by different electronic gadgets like RFID 
tag, sensors, cameras will be processed through edge cloud and big data analytics for traffic management through smart roads

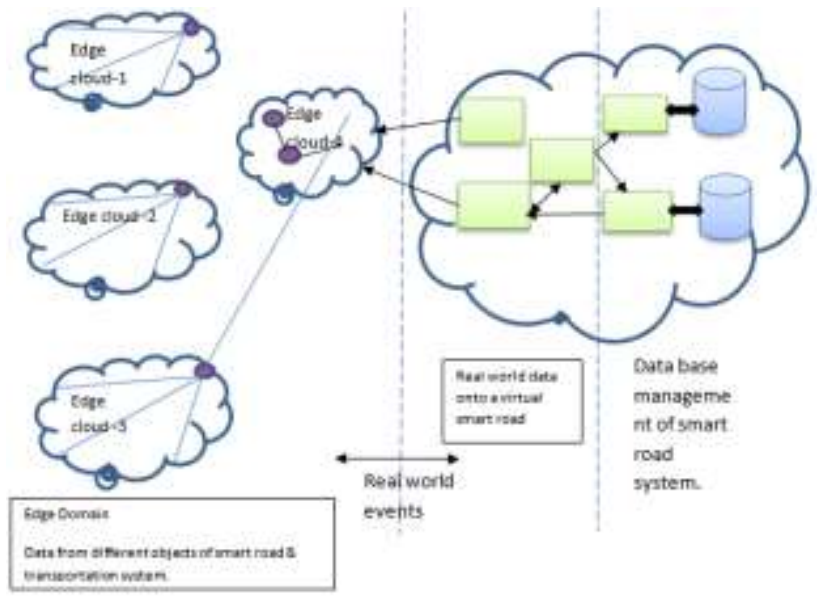

Fig. 1: Smart road system: conceptualization - using big data analytics (Adopted with modifications from Foundations for smarter cities. C. Harrisonet.al)

Interactions between the real world data and virtual systems using ICT and IOT is demonstrated through the following diagrams given in Fig-2

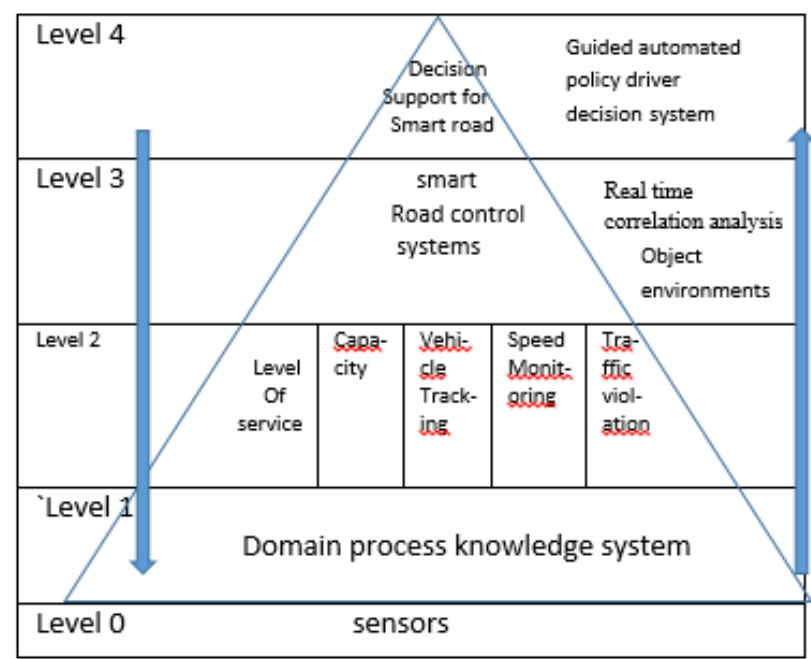

Fig. 2: Layered structured interconnections for smart road system (Adopted with modifications from foundations for smart cities $C$. Harrison et.al).

\section{Current Traffic Assessment: Express Highway in} Muscat City A Case Study:

Muscat the capital of Sultanate of Oman 40 years ago was a sleepy port town with about 40,000 populations and reached 1.5 Million in the year 2017. The Muscat Metropolitan area is stretched over a length of $60 \mathrm{~km}$ with a geographical area of 3500Sq.km. Developments in Muscat is restricted by the geographical constraints of $50 \mathrm{~km}$ coast line in the East and Al Hajar Mountains on the Western side, and as most of the area is covered by deserts very limited land is available for mixed land use developments.
Muscat Expressway and Seeb-Sultan Quaboos Street are the major arterials running North-South driving the directional growth of the Muscat Urban Agglomeration (Figure-3).

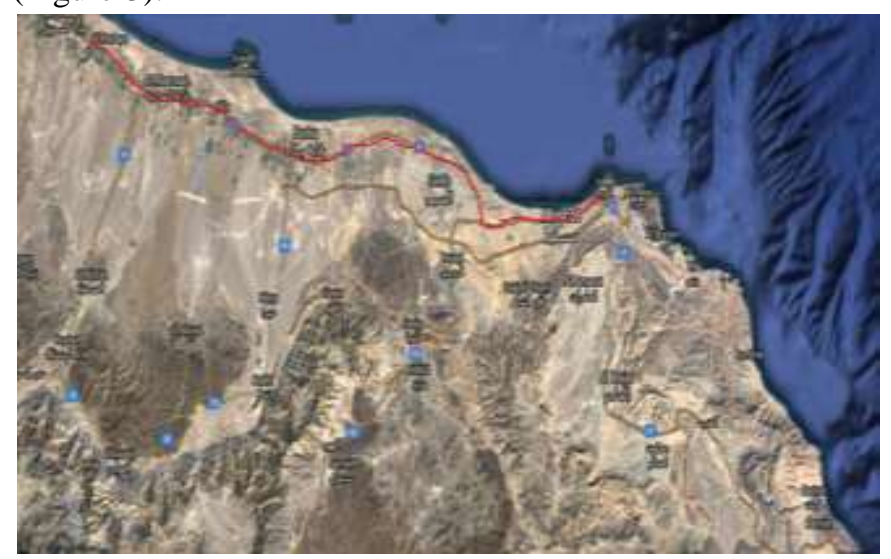

Fig. 3: Muscat Urban agglomeration showing the corridor where speeds captured

To capture the operating speeds during peak and non-peak hour vehicle speeds has been captured with the help of radar guns. The vehicle speeds are used in estimation of the $85^{\text {th }}$ percentile speed. Operating speeds (mid-block) captured on between Al Hail and Airport section is presented in the following tables-1.

Table.1: Spot speeds captured on the mid-block during

\begin{tabular}{|c|c|c|c|c|c|}
\hline \multicolumn{6}{|c|}{ non-peak hour } \\
\hline $\begin{array}{l}\text { Spee } \\
\text { d } \\
\text { KM } \\
\text { PH }\end{array}$ & $\begin{array}{l}\text { Mea } \\
\mathrm{n} \\
\text { Spe } \\
\text { ed }\end{array}$ & $\begin{array}{l}\text { Numb } \\
\text { er of } \\
\text { Vehicl } \\
\text { e } \\
\text { Recor } \\
\text { ded }\end{array}$ & $\begin{array}{l}\text { frequency*S } \\
\text { peed }\end{array}$ & $\begin{array}{l}\text { Freque } \\
\text { ncy } \\
(\%)\end{array}$ & $\begin{array}{l}\text { Cumula } \\
\text { tive } \\
\text { Frequen } \\
\text { cy }\end{array}$ \\
\hline $\begin{array}{l}30- \\
40\end{array}$ & 35 & 0 & 0 & $0 \%$ & $0 \%$ \\
\hline $\begin{array}{l}40- \\
50\end{array}$ & 45 & 3 & 135 & $1 \%$ & $1 \%$ \\
\hline $\begin{array}{l}50- \\
60\end{array}$ & 55 & 15 & 825 & $3 \%$ & $3 \%$ \\
\hline $\begin{array}{l}60- \\
70\end{array}$ & 65 & 20 & 1300 & $3 \%$ & $6 \%$ \\
\hline $\begin{array}{l}70- \\
80\end{array}$ & 75 & 28 & 2100 & $5 \%$ & $11 \%$ \\
\hline $\begin{array}{l}80- \\
90\end{array}$ & 85 & 36 & 3060 & $6 \%$ & $17 \%$ \\
\hline $\begin{array}{l}90- \\
100\end{array}$ & 95 & 58 & 5510 & $10 \%$ & $27 \%$ \\
\hline $\begin{array}{l}100- \\
110\end{array}$ & 105 & 75 & 7875 & $13 \%$ & $40 \%$ \\
\hline $\begin{array}{l}110- \\
120\end{array}$ & 115 & 122 & 14030 & $21 \%$ & $61 \%$ \\
\hline $120-$ & 125 & 167 & 20875 & $28 \%$ & $89 \%$ \\
\hline
\end{tabular}




\begin{tabular}{|l|r|r|r|r|r|}
\hline 130 & & & & & \\
\hline $\begin{array}{l}130- \\
140\end{array}$ & 135 & 65 & 8775 & $11 \%$ & $100 \%$ \\
\hline & & 589 & 64485 & $100 \%$ & \\
\hline
\end{tabular}

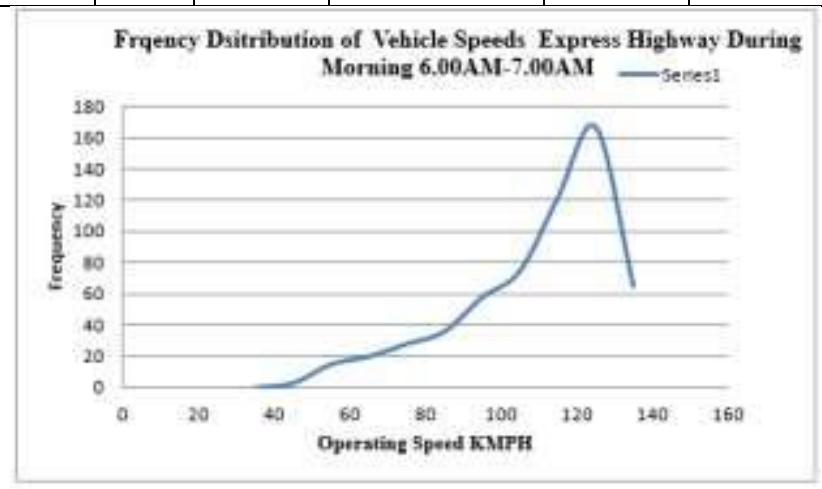

Fig. 4: Frequency Distribution of Vehicle Speeds on Express Highway During Morning Peak 7.00AM-8.00AM.

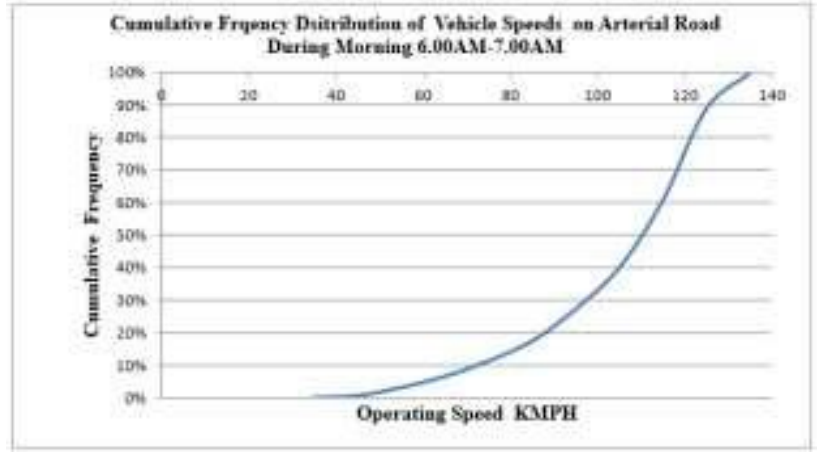

Fig.5: Frequency Distribution of Vehicle Speeds on Express Highway during Morning 7.00AM-8.00AM Peak Hours

Table.2: Vehicle Speeds on Express Highway during Morning 7.00AM-8.00AM Peak Hours

\begin{tabular}{|c|c|c|c|c|c|}
\hline $\begin{array}{l}\text { Mean } \\
\text { Spee } \\
\text { d }\end{array}$ & $\begin{array}{l}\text { Spe } \\
\text { ed } \\
\mathrm{K} \\
\mathrm{MP} \\
\mathrm{H}\end{array}$ & $\begin{array}{l}\text { Numb } \\
\text { er of } \\
\text { Vehicl } \\
\text { e } \\
\text { Recor } \\
\text { ded }\end{array}$ & $\begin{array}{l}\text { frequency* } \\
\text { Speed }\end{array}$ & $\begin{array}{l}\text { Freque } \\
\text { ncy } \\
(\%)\end{array}$ & $\begin{array}{l}\text { Cumula } \\
\text { tive } \\
\text { Frequen } \\
\text { cy }\end{array}$ \\
\hline $\begin{array}{l}30- \\
40\end{array}$ & 35 & 54 & 1890 & $9 \%$ & $9 \%$ \\
\hline $\begin{array}{l}40- \\
50\end{array}$ & 45 & 75 & 3375 & $12 \%$ & $21 \%$ \\
\hline $\begin{array}{l}50- \\
60\end{array}$ & 55 & 96 & 5280 & $15 \%$ & $36 \%$ \\
\hline $\begin{array}{l}60- \\
70\end{array}$ & 65 & 106 & 6890 & $17 \%$ & $53 \%$ \\
\hline $\begin{array}{l}70- \\
80\end{array}$ & 75 & 135 & 10125 & $22 \%$ & $75 \%$ \\
\hline $\begin{array}{l}80- \\
90\end{array}$ & 85 & 77 & 6545 & $12 \%$ & $87 \%$ \\
\hline 90- & 95 & 64 & 6080 & $10 \%$ & $97 \%$ \\
\hline
\end{tabular}
sources and speed survey, the analysis of the data give the following observations:

Designed speed for the express highway is $120 \mathrm{Kmph}$.

- About 590 cars are captured and their speeds are mapped to obtain 85 th percentile speed.

- 85 th percentile speed during the peak hour is $124 \mathrm{Kmph}$ which is more than the designed speed.

- Mean Speed during non-peak hours is $109 \mathrm{kmph}$.

- 85 th percentile speed during peak hour is $80 \mathrm{Kmph}$ and mean speed is $67 \mathrm{Kmph}$

Level of Service and Capacity analysis: 
Traffic volumes are also captured to assess the level of service during the peak hour for the arterial road under study. Designed speed for the Arterial Road is $120 \mathrm{Kmph}$. Capacity of the road per lane per $\mathrm{km}$ is estimated using the expression $1000 \mathrm{~V} / \mathrm{S}$ where $\mathrm{V}$ is designed speed and $\mathrm{S}$ is the vehicle to vehicle distance. For the given road capacity of the road is arrived at as 1500 vehicles /lane/hour.

Table.3: Traffic Volumes and Level of Service on the Road during morning Peak

\begin{tabular}{|l|l|l|l|l|l|l|l|l|l|l|l|l|}
\hline \multicolumn{1}{|l|}{ Tuesday18.04.2017 } & \multicolumn{9}{|c|}{ Direction: AlHail To Airport } \\
\hline $\begin{array}{l}\text { Time } \\
\text { Morning Peak }\end{array}$ & $\begin{array}{l}\text { Small } \\
\text { cars }\end{array}$ & $\begin{array}{l}\text { Big } \\
\text { cars }\end{array}$ & Pick up & Trucks & $\begin{array}{l}2 \\
\text { Axel }\end{array}$ & 3 Axel & Bus & $\begin{array}{l}\text { Total } \\
\text { Vehi } \\
\text { cles }\end{array}$ & $\begin{array}{l}\text { Total } \\
\text { PCU }\end{array}$ & $\begin{array}{l}\text { Capa } \\
\text { city }\end{array}$ & $\begin{array}{l}\text { Volum } \\
\text { e/Capa } \\
\text { city }\end{array}$ & $\begin{array}{l}\text { L } \\
\text { O } \\
\text { S }\end{array}$ \\
\hline PCU & 1 & 1.5 & 1.5 & 3 & 3 & 4.5 & 3 & & & & & \\
\hline $6: 00-7: 00$ & 228 & 198 & 25 & 4 & 7 & 4 & 45 & 511 & 749 & 1500 & 0.5 & A \\
\hline $7: 00-8: 00$ & 1240 & 485 & 250 & 0 & 0 & 0 & 100 & 2075 & 2643 & 1500 & 1.76 & D \\
\hline $8: 00-9: 00$ & 1400 & 750 & 348 & 0 & 0 & 0 & 66 & 2564 & 3245 & 1500 & 2.16 & F \\
\hline 9:00-10:00 & 950 & 400 & 202 & 3 & 3 & 1 & 18 & 1577 & 1930 & 1500 & 1.29 & C \\
\hline 10:00-11:00 & 750 & 302 & 158 & 4 & 1 & 0 & 9 & 1224 & 1482 & 1500 & 0.99 & $\mathrm{C}$ \\
\hline
\end{tabular}

Table.4: Traffic Volumes and Level of Service on Express Highway during morning Peak

\begin{tabular}{|l|l|l|l|l|l|l|l|l|l|l|l|l|}
\hline \multicolumn{10}{|l|}{ Tuesday18.04.2017 } & \multicolumn{10}{|l|}{ Direction: Airport to Al Hail } \\
\hline $\begin{array}{l}\text { Time } \\
\text { evening } \\
\text { Peak }\end{array}$ & $\begin{array}{l}\text { Small } \\
\text { cars }\end{array}$ & $\begin{array}{l}\text { Big } \\
\text { cars }\end{array}$ & $\begin{array}{l}\text { Pick } \\
\text { up }\end{array}$ & Trucks & $\begin{array}{l}2 \\
\text { Axel }\end{array}$ & 3 Axel & Bus & $\begin{array}{l}\text { Total } \\
\text { Vehic } \\
\text { les }\end{array}$ & $\begin{array}{l}\text { Tota } \\
1 \\
\text { PCU }\end{array}$ & $\begin{array}{l}\text { Capa } \\
\text { city }\end{array}$ & $\begin{array}{l}\text { Volu } \\
\text { me/C } \\
\text { apacit } \\
\text { y }\end{array}$ & $\begin{array}{l}\text { L } \\
\text { O } \\
\text { S }\end{array}$ \\
\hline 2:00-3:00 & 250 & 221 & 35 & 15 & 5 & 4 & 62 & 592 & 888 & 1500 & 0.59 & A \\
\hline 3:00-4:00 & 1345 & 465 & 215 & 5 & 2 & 2 & 109 & 2143 & 2719 & 1500 & 1.81 & D \\
\hline 4:00-5:00 & 1312 & 688 & 485 & 8 & 7 & 2 & 69 & 2571 & 3325 & 1500 & 2.22 & F \\
\hline 5:00-6:00 & 1054 & 412 & 214 & 10 & 8 & 7 & 19 & 1724 & 2127 & 1500 & 1.42 & C \\
\hline 6:00-7:00 & 685 & 342 & 112 & 6 & 4 & 5 & 10 & 1164 & 1443 & 1500 & 0.96 & C \\
\hline
\end{tabular}

Inferences on traffic volumes and level of services for the peak hour are presented below:

Morning and evening peak traffic volume on the road reveal they are beyond the capacity and level of service is falling from $A$ to $F$. There is need for effective monitoring of traffic management

Smart Road Technology:

Major benefits of adopting Smart Road Technologies are:

- Improved traffic Safety

- Reduced congestion.

- Improved access to jobs and services

- Improved accessibility and mobility

- Reduced transportation cost for Government and users
- Traffic management through the area integration and monitoring

- Effective travel road guidance information systems to road users.

Current traffic situation indicates the need for traffic management and it can be achieved through adoption of smart road technology, which is demonstrated in the previous paragraphs. For the implementation of the smart road systems on a normal conventional road, IT infrastructure is assessed and is presented below. The arterial road section selected for the selection of the smart road technology is a part of Al-Hail -Airport road in Muscat and is shown in the in the map below in Figure 7 


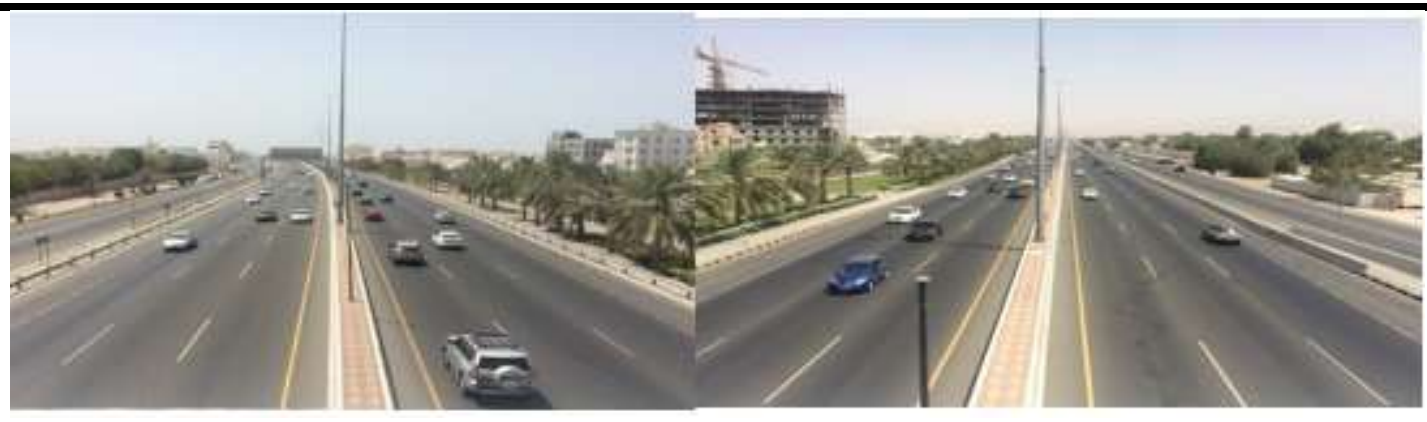

Fig. 7: Road Segment selected for implementation of the Smart Road Technology

\section{IT Infrastructure Design:}

Electronic devices and gadgets required for a length of $10 \mathrm{~km}$ is assessed and presented below. ICT operations involved in the real world situations for the arterial road is demonstrated below in figure: 8 For vehicle tracking and capturing all the vehicles crossing a particular section of the road all the vehicles should be fitted with the RFID tag. Use of RFID in smart road is demonstrated in Figure:9

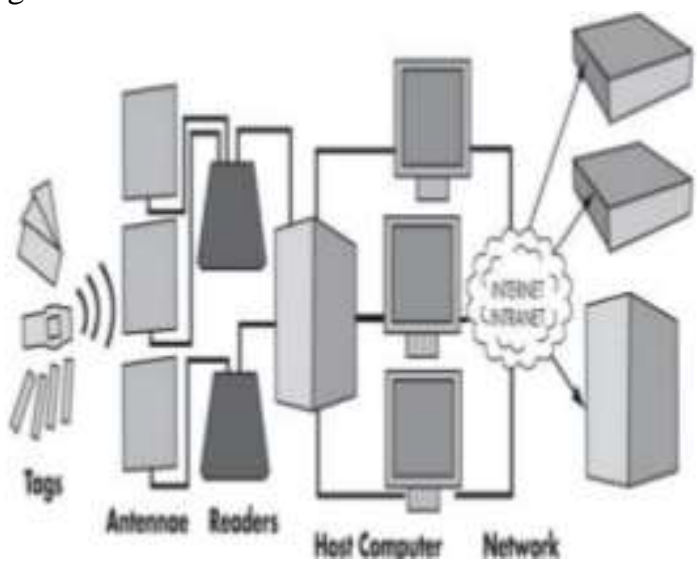

Fig. 8: RFID in Smart Road System(Source :https://www.slideshare.net/rameshchatty/rfid-basedtraffic-control-system-by-using-gsm)

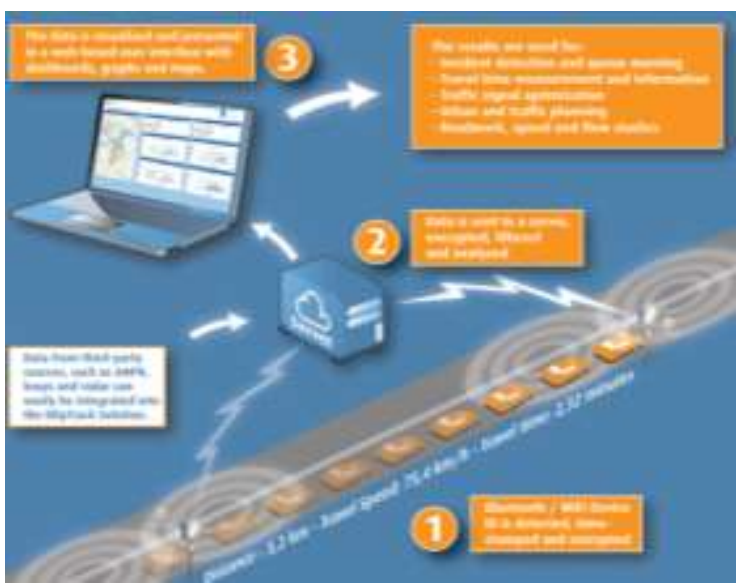

Fig. 8: Demonstration of use of RFID in Smart Road System
Table: 5 IT infrastructure Requirements for the conversion of a Normal Road into a Smart Road

\begin{tabular}{|l|l|l|l|l|}
\hline $\begin{array}{l}\text { Distance } \\
(\mathbf{K m})\end{array}$ & \multicolumn{2}{|l|}{ NO. of Sensors } & NO. of Camera & Server \\
\hline & Left & Right & & \\
\hline $1 \mathrm{Km}$ & One & & - & - \\
\hline $2 \mathrm{Km}$ & & One & 2 in both sides & - \\
\hline $3 \mathrm{Km}$ & One & & - & - \\
\hline $4 \mathrm{Km}$ & & One & 2 in both sides & - \\
\hline $5 \mathrm{Km}$ & One & & & 1 \\
\hline $6 \mathrm{Km}$ & & One & 2 in both sides & - \\
\hline $7 \mathrm{Km}$ & One & & - & - \\
\hline $8 \mathrm{Km}$ & & One & 2 in both sides & - \\
\hline $9 \mathrm{Km}$ & One & & - & - \\
\hline $10 \mathrm{Km}$ & & One & 2 in both sides & \\
\hline TOTAL & 5 & 5 & 10 Cameras & \begin{tabular}{l} 
Servers \\
\hline
\end{tabular} \\
\hline
\end{tabular}

Apart from the IT infrastructure, there is a need for the establishment of centralized traffic control room to monitor the traffic management systems. Also making a segment of the road as smart road will not be serving the purpose. All the primary roads in the region should be interconnected for achieving effective traffic management.

\section{CONCLUDING REMARKS}

In this technical paper current issues in traffic with respect to safety and level of service are evaluated on the Express Highway and the concerns are highlighted. Role of Smart Road technologies as an effective way of finding the cost effective solutions to the current traffic problems is emphasized. Working principles of smart road are discussed. To convert the Express Highway into a smart road, IT infrastructure requirement is arrived at. This technical paper is intended for demonstration only, for which a stretch of about $10 \mathrm{Km}$ is examined for demonstrative purposes. A detailed study need to be carried for the complete assessment of IT infrastructure and for the conversion of express highway network into a smart road system. 


\section{REFERENCES}

[1] C. Harrison, B. Eckman, R. Hamilton, P. Hartswick, J. Kalagnanam, J. Paraszczak, and P. Williams. Foundations for smarter cities. IBM Journal of Research and Development, 54:116, 2010.

[2] C. H. Chen-ritzo, C. Harrison, F. Parr, and J. Paraszczak, B., Instrumenting the planet, IBM J. Res. \& Dev., vol. 53, no. 3, paper 1, pp. 1-16, 2009.

[3] Internet of Things An Action Plan for Europe. [Online]. Available: http://ec.europa.eu/information_society/ policy/rfid/documents/commiot2009.pdf

[4] ABI Research, Intelligent Transportation Systems Market Overview, 2009. [Online]. Available: http://www.abiresearch.com/

[5] research/1003306Intelligent+Transportation+System s+Market+ Overview International Telecommunications Union, Measuring the Information Society, The ICT Development Index. [Online]. Available: http://www.itu.int/ITUD/ict/publications/idi/2009/ material/IDI2009_w5.pdf

[6] M. Haghighat, S. Zonouz, \& M. Abdel-Mottaleb (2015). CloudID: Trustworthy Cloud-based and Cross-Enterprise Biometric Identification. Expert Systems with Applications, 42(21), 7905-7916

[7] Hamadaqa, Mohammad (2012). Cloud Computing Uncovered: A Research Landscape (PDF). Elsevier Press. pp. 41-85. ISBN 0-12-396535-7

[8] OASIS Reference Model for Service-Oriented Architecture 1.0. [Online]. Available: http://www.oasis-open.org/committees/ download.php/19679/soa-rm-cs.pdf

[9] Sonoma County Water Agency. [Online]. Available: http://www.scwa.ca.gov/

[10] Stockholm Trial, Facts About the Evaluation of the Stockholm Trial. [Online]. Available: http://www.stockholmsforsoket.se/ upload/Hushall_eng.pdf

[11]Land Transport Authority, Singapore Government, Electronic Road Pricing. [Online]. Available: http://www.lta.gov.sg/ motoring_matters/index_motoring_erp.htm

[12]IBM Corporation, IBM CityForward. [Online]. Available: http://cityforward.org

[13] Nirav Thakor, Tanmay Vyas and Divyang Shah (2013). "Automatic Vehicle Accident Detection System Based on ARM \&GPS" International Journal for Research in Technological Studies, Vol-1, Issue 1, Dec 2013 